\title{
Seasonal variation and ecological importance of tannin and nutrient concentrations in Casuarina equisetifolia branchlets and fine roots
}

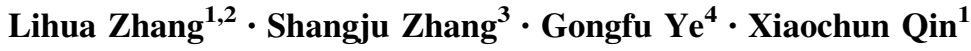

Received: 4 December 2017 / Accepted: 9 December 2018/Published online: 7 June 2019

(C) The Author(s) 2019

\begin{abstract}
In this study, we investigated the effects of environmental factors on plant phenolic variability, seasonal dynamics of total phenolic content (TP), extractable condensed tannins (ECT), protein-bound condensed tannins (PBCT), fiber-bound condensed tannins (FBCT), total condensed tannins (TCT), protein precipitation capacity (PPC) and nutrient content in the branchlets and fine roots of Casuarina equisetifolia. TP and TCT concentrations in branchlets were lowest in the spring, then increased in summer and autumn, similar to the seasonal dynamics in air temperature. TP and TCT concentrations in fine roots were highest in summer, coinciding with heavy
\end{abstract}

Project funding: This research was supported by the National Natural Science Foundation of China (Nos. 41201293, 31622007, 31670237).

The online version is available at http://www.springerlink.com

Corresponding editor: Zhu Hong.

Lihua Zhang

bio_zhanglh@ujn.edu.cn

$\triangle$ Xiaochun Qin

qinxiaochun@vip.163.com

1 School of Biological Science and Technology, University of Jinan, Jinan 250022, People's Republic of China

2 Key Laboratory of Coastal Environmental Processes and Ecological Remediation, Yantai Institute of Coastal Zone Research (YIC), Chinese Academy of Sciences (CAS), Shandong Provincial Key Laboratory of Coastal Environmental Processes, YICCAS, Yantai 264003, People's Republic of China

3 Pingtan State-Owned Protection Forest Farm of Fujian Province, Pingtan 350400, People's Republic of China

4 Fujian Academy of Forestry, Fuzhou 350012, People's Republic of China precipitation. In general, TP and TCT concentrations were higher in branchlets than in fine roots. No significant difference was found in $\mathrm{C}$ concentration among various seasons for either branchlets or fine roots. Branchlets had significantly higher $\mathrm{N}$ and $\mathrm{P}$ concentrations than fine roots in most seasons. The $\mathrm{C} / \mathrm{N}$ and $\mathrm{N} / \mathrm{P}$ ratios in branchlets were significantly lower than in fine roots in all seasons, except summer. The relationship between branchlets and fine roots was significant for $\mathrm{C}, \mathrm{P}$ and $\mathrm{FBCT}$, but no significant relationships were found for N, TP, ECT, PBCT and TCT. Additionally, TP and TCT content were each significantly correlated with PPC in branchlets and in fine roots. Both $\mathrm{TP} / \mathrm{N}$ and TCT/N ratios were highest in the autumn for the branchlets and in the summer for fine roots. The results indicate that high temperatures lead to increased tannin production in branchlets, but that the tannin content in fine roots is mainly affected by precipitation. Tannin content was greater in branchlets than in fine roots, which may indicate that selective pressure is greater on branchlets than on fine roots.

Keywords Casuarina equisetifolia - Condensed tannins . Total phenolic content $\cdot$ Nutrient $\cdot$ Seasonal variation

\section{Introduction}

Phenolic compounds, including tannins, are a significant component of plant secondary metabolites (Izquierdo et al. 2011) in leaves, roots, bark, flowers and fruits, thus, holding a large portion of carbon in terrestrial biomass. Only the proportion of carbon stock in cellulose, hemicellulose and lignin in vascular plant tissue is greater (Hernes et al. 2001; Hernes and Hedges 2000). In some cases, tannin levels exceed lignin levels in leaves and 
needles (Hernes et al. 2001). Across the ecosystem, tannins are widely distributed within living plant matter, litter, and soil. Tannins are complex molecules that are energetically costly to synthesize, so their widespread distribution and abundance indicates that they play an important role in plant function and evolution (Kraus et al. 2003; Wam et al. 2017).

Although the physiological basis and ecological consequences of leaf phenolics in plant tissues have been studies, only a few extensive data sets have been compiled to evaluate temporal variations in plant phenolics (Covelo and Gallardo 2001; Wang et al. 2007, 2008).

While the seasonal changes in aboveground tannins are well known (Naumann et al. 2017; Yang et al. 2018), the effect of seasonal variation in polyphenolics in fine roots (i.e., $<2 \mathrm{~mm}$ in diameter) has received much less attention. The content of plant phenolics varies seasonally among organs and tissues and in response to many biotic and abiotic factors, including nutrient content, water availability, $\mathrm{CO}_{2}$ level, light availability and temperature (Duda et al. 2015; Kim et al. 2013; Pacifico et al. 2015). The carbon-nutrient balance (CNB) hypothesis (Bryant et al. 1983) and the growth-differentiation balance (GDB) hypothesis (Herms and Mattson 1992) both suggest that the secondary compound concentrations change with resource availability. However, these hypotheses have not always been supported by direct evidence. Thus, additional studies on the seasonal dynamics of tannins and nitrogen content in plant are necessary.

Australian native Casuarinaequisetifolia is a nitrogenfixing tree of considerable social, economic, and environmental importance in tropical and subtropical littoral zones of Asia, the Pacific and Africa (Zhang et al. 2008). It is commonly used in agroforestry systems for soil stabilization, reclamation, coastal protection and ecosystem rehabilitation (Pinyopusarerk and Williams 2000). C.equisetifolia is high in tannins and frequently grows in infertile and sandy arid coastal areas along the coast of South China. The leaves of C.equisetifolia are reduced, small scales, occurring in whorls at joints (nodes) along the length of the branchlets.

Zhang et al. (2009) investigated the seasonal dynamics of tannins in young, mature and senescent branchlets in a C. equisetifolia plantation. However, whether tannin variation is comparable in fine roots and branchlets is unknown. Therefore, here we investigated the seasonal dynamics of tannin and nutrient content in mature branchlets and fine roots of $C$. equisetifolia to determine the difference in allocation of plant phenolics between above- and below-ground biomass. We tested the following hypotheses: (1) Tannin content in C. equisetifolia branchlets and fine roots increases simultaneously under severe stress, such as high temperature, waterlogging or drought.
(2) Tannin production in branchlets and fine roots is coregulated by climatic conditions and nutrient content in the organs, so a large increase in production is a result of intense environmental pressures and nutrient limitation for branchlets, but not for roots. We tested these hypotheses in a field investigation at the Chishan Forestry Center in Dongshan County, Fujian Province, China to reveal the significance of tannin production for the growth and survival of $C$. equisetifolia in arid and infertile environments.

\section{Materials and methods}

\section{Study site}

The study was carried out at the Chishan Forestry Center in Dongshan County $\left(23^{\circ} 40^{\prime} \mathrm{N}, 118^{\circ} 55^{\prime} \mathrm{E}\right)$, Fujian Province, China. The region has a southern subtropical maritime monsoon climate, with annual temperatures ranging from 3.8 to $36.6{ }^{\circ} \mathrm{C}$. Mean annual precipitation and evaporation are 1103.8 and $2027.9 \mathrm{~mm}$, respectively. The rainy season lasts from March to October, and the dry season lasts from November to February. The soils are coastal, sandy and barren with a $\mathrm{pH} 4.1-4.4$.

The $C$. equisetifolia plantations sampled in this study were pure forests that had been artificially planted in 1992 . The canopy coverage was 0.7 ; tree density was 1552 tree $\mathrm{ha}^{-1}$; canopy height ranged from 5-7 $\mathrm{m}$ and diameter at breast height $(\mathrm{DBH})$ was $8.1 \mathrm{~cm}$. The average $\mathrm{N}$ and $\mathrm{P}$ content at $20 \mathrm{~cm}$ depth in the soil was 54.49 and $2.69 \mathrm{mg} \mathrm{kg}^{-1}$, respectively. Soil $\mathrm{pH}$ was 4.19 .

\section{Materials}

Thirty individuals of $C$. equisetifolia were chosen, divided into six groups (five trees per group) and labeled. The height and growth conditions were similar among the selected trees. Mature branchlets (fully developed, dark green, usually $15-25 \mathrm{~cm}$ long) and fine roots were collected from each tree. Actively growing roots $(<2 \mathrm{~mm}$ diameter) were collected from the upper mineral soil $(0-20 \mathrm{~cm}$ soil depth) with a corer (diam. $8 \mathrm{~cm})$ to extract tannin and nutrients. Branchlets and fine roots of each labeled tree were collected in March, June, September and December of 2015. Branchlets damaged by insects and disease or structural failure were avoided. All samples were taken to the laboratory immediately after sampling and cleaned with distilled water. The washed branchlets and fine roots were flash-cooled in liquid nitrogen, immediately freeze-dried for $48 \mathrm{~h}$ and then ground to pass through a 40 -mesh sieve. The samples were stored at $-20{ }^{\circ} \mathrm{C}$ until analyzed. 
Seasonal climatic data were collected from the Huian Meteorological Bureau in Fujian Province.

\section{Determination of tannin content}

Analytical reagent grade chemicals were used to analyze tannin concentrations (Sinopharm, Shanghai, China). For the standard, tannin was extracted from the C. equisetifolia branchlets and fine roots and purified using Sephadex LH20 resin (Thomas Scientific, Swedesboro, NY, Amersham, USA) as described by Hagerman (2011). The condensed tannin standard was then freeze-dried and stored at -20 ${ }^{\circ} \mathrm{C}$ until required.

Procedures described by Lin et al. (2006) were used to determine amounts of total phenolic content (TP), extractable condensed tannins (ECT), protein-bound condensed tannins (PBCT), fiber-bound condensed tannins (FBCT) and protein precipitation capacity (PPC) in the branchlets and fine roots. TP was measured by the FolinCiocalteu method (Zhou et al. 2010), and ECT, P5BCT and FBCT were assayed using the butanol- $\mathrm{HCl}$ method (Terrill et al. 1992) and standardized tannins from C. equisetifolia branchlets and fine roots. Total condensed tannin (TCT) content was calculated by adding the respective quantities of ECT, PBCT and FBCT (Terrill et al. 1992). A radial diffusion assay was used to determine the protein precipitation capacity (PPC) (Hagerman 1987).

\section{Determination of carbon, nitrogen and phosphorus content}

Total $\mathrm{C}$ and $\mathrm{N}$ content of branchlets and fine roots was determined with ground subsamples measured by the Elementar CHNS analyzer model Vario EL III (Vario EL, Elementar Analyser systeme $\mathrm{GmbH}$, Hanau, Germany). Plant samples were processed with sulfuric acid and hydrogen peroxide, and then the $\mathrm{P}$ content was determined by the ascorbic acid-antimony reducing phosphate colorimetric method (Institute of Soil Science 1978).

\section{Statistical analyses}

All measurements were done six times. Mean and standard deviation values of triplicate samples were calculated and analyzed using a one-way ANOVA. The Student-Newman-Keuls multiple comparison method was used to test significant differences among the seasons. All analyses were performed in SPSS 20.0 for Windows.

\section{Results}

\section{Seasonal dynamics of precipitation and air temperature}

As shown in Fig. 1, the air temperature ranged from 11.35 to $18.42{ }^{\circ} \mathrm{C}$, from 24.21 to $28.76{ }^{\circ} \mathrm{C}$, from 24.64 to $29.95{ }^{\circ} \mathrm{C}$ and from 13.79 to $18.67{ }^{\circ} \mathrm{C}$, with precipitation measuring 77.59, 214.33, 113.9 and $25.7 \mathrm{~mm}$ in March, June, September and December, respectively.

\section{Seasonal dynamics of total phenolic content}

TP content was higher in branchlets (ranging from 69.49 to $100.00 \mathrm{mg} \mathrm{g}^{-1}$ ) than in fine roots (ranging from 48.68 to $70.75 \mathrm{mg} \mathrm{g}^{-1}$ ) across all seasons (Fig. 2). The TP content of branchlets and fine roots was highest in autumn and summer, respectively.

\section{Seasonal dynamics of condensed tannin content}

ECT content in branchlets $\left(173.87 \mathrm{mg} \mathrm{g}^{-1}\right)$ and fine roots $\left(121.24 \mathrm{mg} \mathrm{g}^{-1}\right)$ was highest in autumn and in summer, respectively, and lowest, 72.47 and $82.66 \mathrm{mg} \mathrm{g}^{-1}$, were in the spring (Fig. 3a). The ECT content was lower in branchlets than in fine roots in the spring and summer, but was higher in the autumn and winter.

PBCT content was significantly higher in branchlets (ranging from 9.39 to $12.94 \mathrm{mg} \mathrm{g}^{-1}$ ) than in fine roots (ranging from 5.32 to $7.43 \mathrm{mg} \mathrm{g}^{-1}$ ) (Fig. 3b). PBCT content in both branchlets and fine roots was highest in autumn and summer, respectively, similar to ECT. However, FBCT content in the branchlets increased during the growing season, then decreased in the winter (Fig. 3c). On the contrary, the FBCT content of fine roots initially decreased, then increased, and was lowest in the autumn. The FBCT

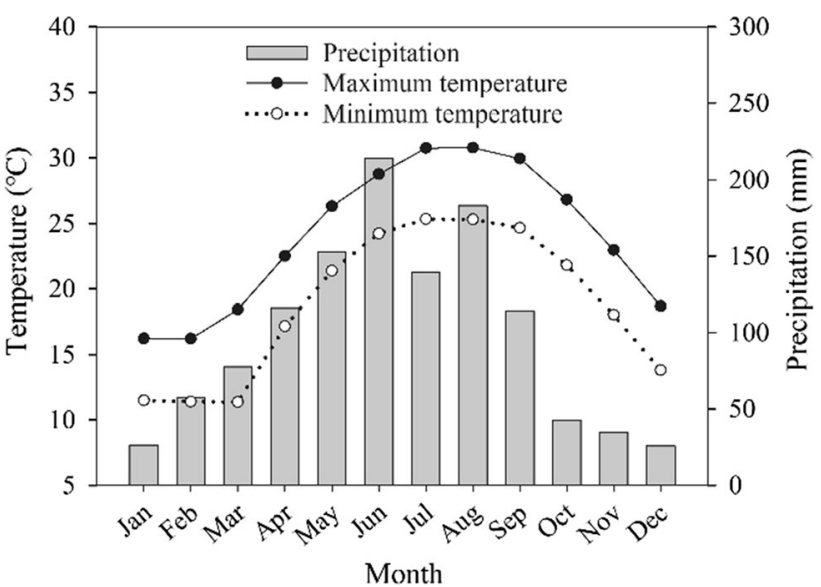

Fig. 1 Seasonal dynamics of precipitation and air temperature in Dongshan County, Fujian Province 


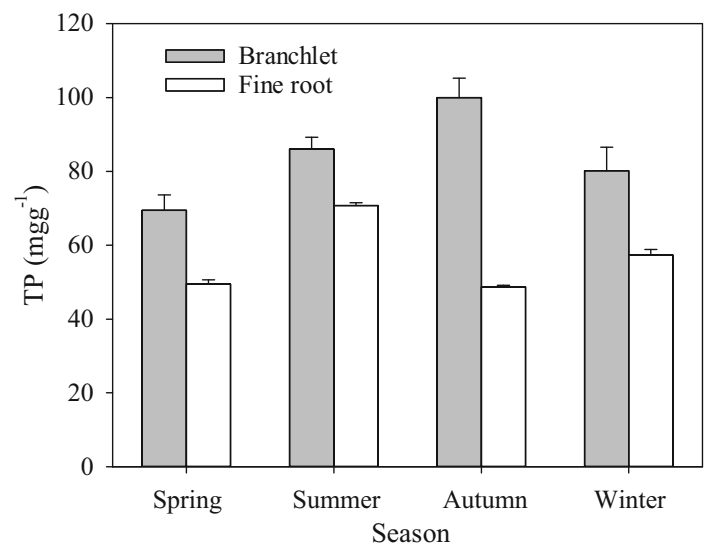

Fig. 2 Seasonal changes in total phenolic (TP) contents of Casuarina equisetifolia branchlets and fine roots

content was significantly higher in fine roots than in branchlets across all seasons. The TCT content was variable, similar to that of the ECT content (Fig. 3d).
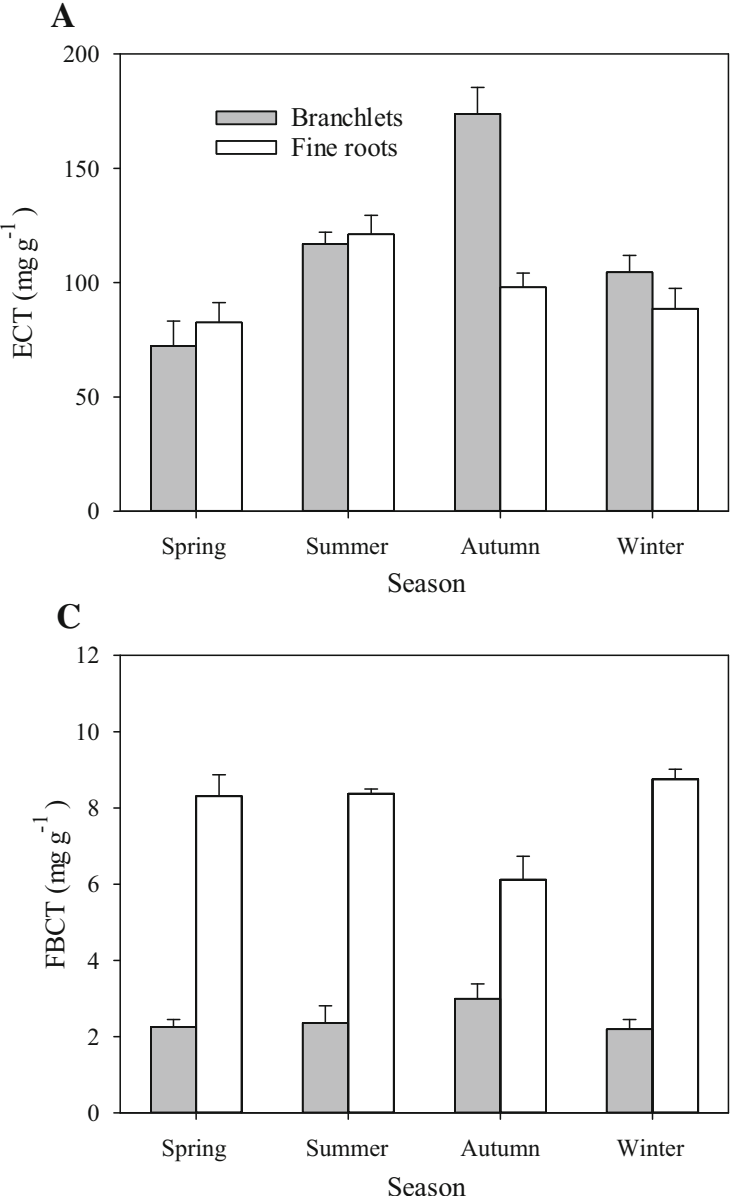

\section{Seasonal dynamics of $\mathrm{C}, \mathrm{N}$ and $\mathrm{P}$ contents, $\mathrm{C} / \mathrm{N}$ and $\mathrm{N} / \mathrm{P}$ ratios}

There was no significant difference in $\mathrm{C}$ content among the seasons for either branchlets or fine roots (Table 1). C content in branchlets and fine roots was highest in winter and summer, respectively. Branchlets had significantly higher $\mathrm{N}$ content than fine roots in the spring and summer. Both $\mathrm{N}$ maximums occurred in the winter, but the branchlet and fine root minimums occurred in spring and summer, respectively. Similarly, branchlets contained significantly higher $\mathrm{P}$ than fine roots. $\mathrm{P}$ content in both initially decreased, then increased in the winter, with the minimum for each in the autumn. The $\mathrm{C} / \mathrm{N}$ and $\mathrm{N} / \mathrm{P}$ ratios in branchlets were significantly lower than in fine roots in all seasons, except for summer.

\section{Seasonal dynamics of TP/N and TCT/N ratios}

The $\mathrm{TP} / \mathrm{N}$ ratio ranged from 4.31 to 5.93 in branchlets and from 4.02 to 7.05 in fine roots (Fig. 4a). The TP/N ratio in

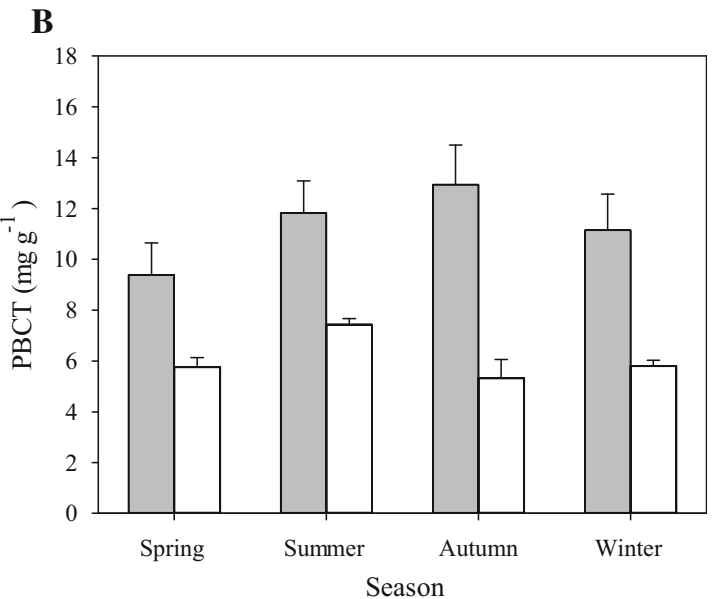

D

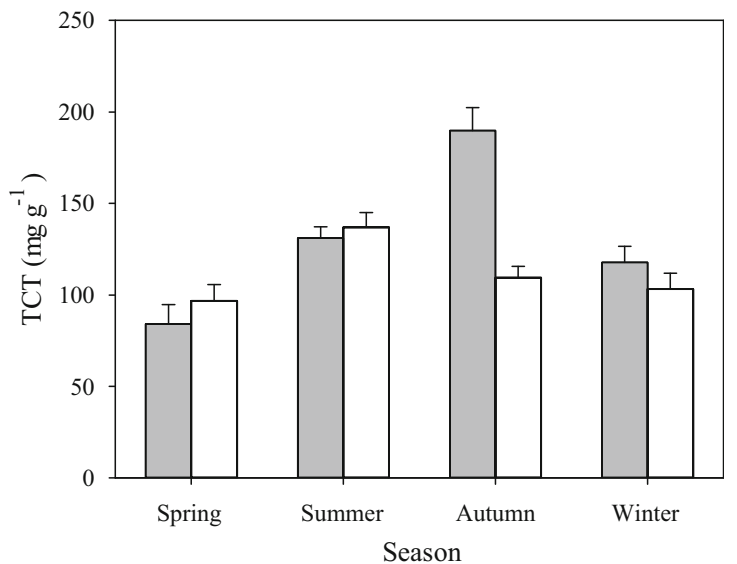

Fig. 3 Seasonal changes in extractable condensed tannin (ECT), protein-bound condensed tannin (PBCT), fiber-bound condensed tannin (FBCT) and total condensed tannin (TCT) in Casuarina equisetifolia branchlets and fine roots 


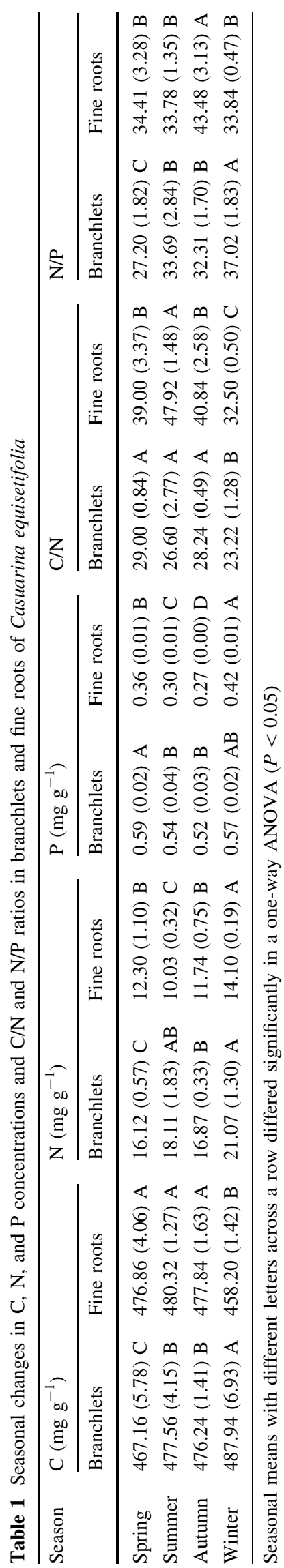


fine roots was higher than in branchlets during the summer, but the opposite was true in autumn. In general, the TCT/N ratio in fine roots (7.32 to 13.66) was higher than in branchlets (5.21-11.25) across all seasons, except for autumn (Fig. 4b). Both the $\mathrm{TP} / \mathrm{N}$ and $\mathrm{TCT} / \mathrm{N}$ ratios in branchlets and in fine roots were highest in autumn and in summer, respectively.

\section{Seasonal dynamics of protein precipitation capacity}

The PPC in branchlets (588.44-702.31 $\mathrm{cm}^{2} \mathrm{~g}^{-1}$ ) was significantly higher than in fine roots (ranging from 462.63 to $612.96 \mathrm{~cm}^{2} \mathrm{~g}^{-1}$ ) (Fig. 5). The highest values in fine roots and branchlets were found in summer and autumn, respectively.

\section{Relationships between different variables}

The paired relationships between $\mathrm{C}, \mathrm{P}$ and FBCT content in branchlets and fine roots were significant, but no significant relationships were found for paired relationships between N, TP, ECT, PBCT and TCT content (Table 2). Additionally, a significant correlation was found among both the TP and TCT contents with PPC in both the branchlets and fine roots.

\section{Discussion}

Seasonal dynamics in plant chemistry during normal growth and differentiation processes reflect changing demands for carbohydrates and nutrients (Penuelas and Estiarte 1998; Usami et al. 2001). According to the GDB (Herms and Mattson 1992) and the CNB hypotheses (Bryant et al. 1983) presented in the introduction, which

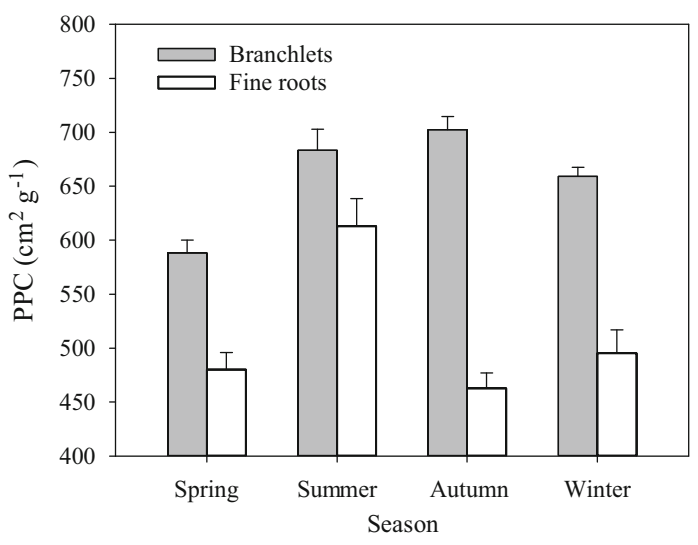

Fig. 5 Seasonal changes in protein precipitation capacity (PPC) of Casuarina equisetifolia branchlets and fine roots

assume that the synthesis of carbon-based secondary chemicals is limited by carbon availability, growth processes take priority over the production of carbon-rich secondary compounds when conditions are favorable for plant growth. Plant growth requires a large amount of carbon, so little carbon is available for carbon-rich secondary metabolites such as phenolics. On the contrary, when growth is not limited by photosynthesis, the carbon allocation increases for defensive compounds (Riipi et al. 2002). According to the GDB hypothesis, carbon availability for phenolics is low in spring when the short-shoot leaves grow rapidly (Riipi et al. 2002), but the phenolic production increases quickly in summer when newly mature leaves experience their highest photosynthetic capacity (Zhang et al. 2009).

Many studies have reported that elevated temperatures reduce TP concentration ( $\mathrm{Li}$ et al. 2011; Mannino et al. 2016; Randriamanana et al. 2015; Sobuj et al. 2018). In the current study, however, both the TP and TCT content in
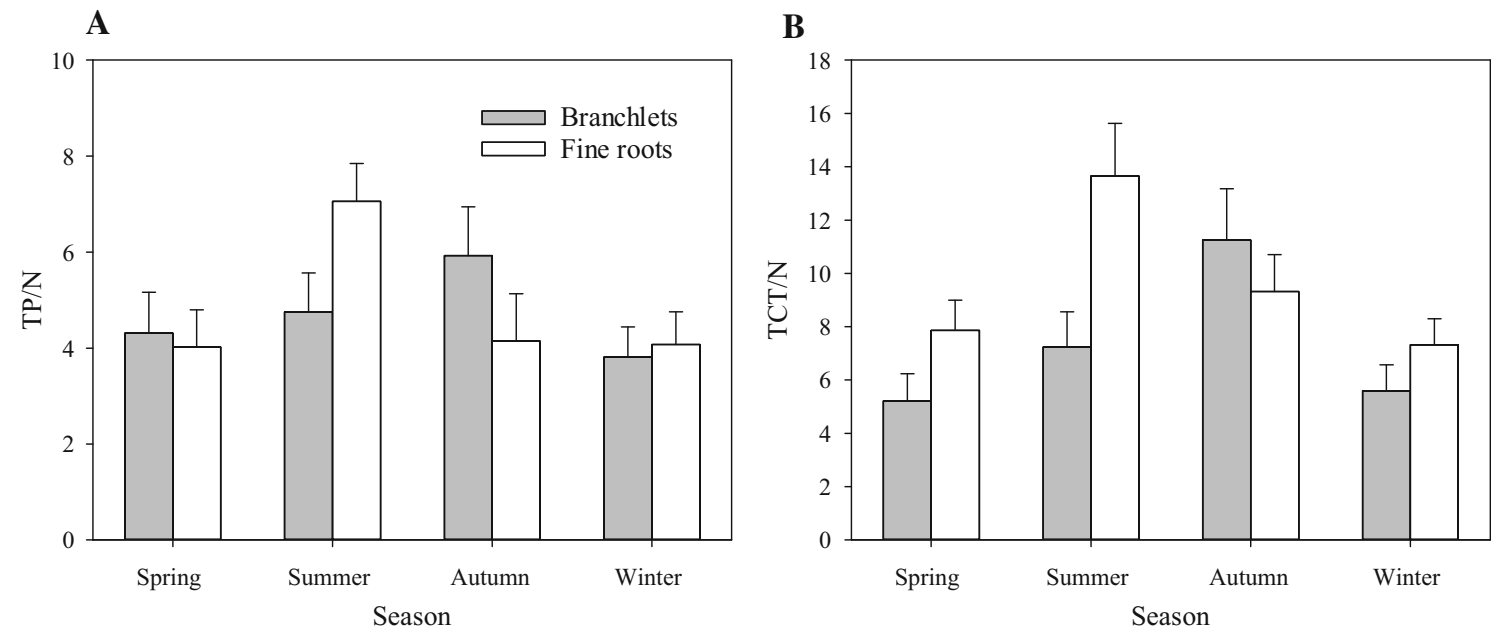

Fig. 4 Seasonal changes in TP/N and TCT/N ratios in Casuarina equisetifolia branchlets and fine roots 
Table 2 Correlation coefficient for paired variables in selected branchlets and fine roots of Casuarina equisetifolia

\begin{tabular}{llrc}
\hline Variable pairs & \multicolumn{1}{l}{$F$} & $P$ \\
\hline $\mathrm{N}_{\mathrm{B}}-\mathrm{N}_{\mathrm{R}}$ & 0.148 & 3.129 & 0.094 \\
$\mathrm{P}_{\mathrm{B}}-\mathrm{P}_{\mathrm{R}}$ & 0.278 & 6.941 & $<0.05$ \\
$\mathrm{C}_{\mathrm{B}}-\mathrm{C}_{\mathrm{R}}$ & 0.372 & 10.672 & $<0.01$ \\
$\mathrm{TP}_{\mathrm{B}}-\mathrm{TP}_{\mathrm{R}}$ & 0.000 & 0.005 & 0.942 \\
$\mathrm{ECT}_{\mathrm{B}}-\mathrm{ECT}_{\mathrm{R}}$ & 0.122 & 2.496 & 0.132 \\
$\mathrm{PBCT}_{\mathrm{B}}-\mathrm{PBCT}_{\mathrm{R}}$ & 0.035 & 0.649 & 0.431 \\
$\mathrm{FBCT}_{\mathrm{B}}-\mathrm{FBCT}_{\mathrm{R}}$ & 0.477 & 16.402 & $<0.01$ \\
$\mathrm{TCT}_{\mathrm{B}}-\mathrm{TCT}_{\mathrm{R}}$ & 0.080 & 1.577 & 0.228 \\
$\mathrm{TP}_{\mathrm{B}}-\mathrm{PPC}_{\mathrm{B}}$ & 0.620 & 40.067 & $<0.001$ \\
$\mathrm{TP}_{\mathrm{R}}-\mathrm{PPC}_{\mathrm{R}}$ & 0.698 & 41.560 & $<0.001$ \\
$\mathrm{TCT}_{\mathrm{B}}-\mathrm{PPC}_{\mathrm{B}}$ & 0.881 & 133.192 & $<0.001$ \\
$\mathrm{TCT}_{\mathrm{R}}-\mathrm{PPC}_{\mathrm{R}}$ & 0.732 & 30.968 & $<0.001$ \\
\hline
\end{tabular}

Subscripts: $B$ branchlets, $R$ fine roots. $N$ nitrogen concentration, $P$ phosphorus concentrations, $T P$ total phenolic concentrations, $E C T$ extractable condensed tannin concentrations, $P B C T$ protein-bound condensed tannin concentrations, $F B C T$ fiber-bound condensed tannin concentrations, TCT total condensed tannin concentrations, $P P C$ protein precipitation capacity

branchlets were lowest in the spring then increased in the summer and autumn, similar to the dynamics of air temperature. This pattern is similar to a finding by Top et al. (2017). On one hand, plants may produce more tannin in warm conditions as a defense strategy to protect the resources that they have already acquired (Herms and Mattson 1992; Massad et al. 2014; Wright et al. 2010). On the other hand, this phenomenon may be attributed to $\mathrm{N}$ limitation due to the warming of air and the stimulated growth of $C$. equisetifolia, which grows in infertile coastal sandy areas. The highest TP and TCT contents in fine roots were found during the summer, when the precipitation was relatively heavy. Many previous studies (Bettaieb et al. 2011; Bucchetti et al. 2011; Top et al. 2017) have shown that water scarcity increases tannin content. However, Lim et al. (2017) found, as we did, that TP content is significantly higher during the wet season than during the rest of the year, thus indicating that waterlogging increases tannin production. Our results suggest that tannin content in the fine roots of $C$. equisetifolia is primarily affected by precipitation, but tannin content in branchlets is primarily affected by temperature. These results partly confirm hypothesis one. However, the fluctuation in content does not necessarily reflect the change in quantitative allocation of tannins to the leaves and roots because labile compounds turn over rapidly (Kleiner et al. 1999), and the content is affected by other components of the leaves, e.g., structural leaf components (Koricheva 1999).
The branchlets had higher TP and TCT contents than in the fine roots. The observed changes in TP and TCT contents in the branchlets and the fine roots agree with the findings reported for different species (Kraus et al. 2004). Branchlets must be well defended with chemical compounds because branchlet damage may reduce photosynthetic ability. Further, because branchlets contain much higher TP and TCT contents than in fine roots, branchlets likely are under more intense selection pressure than fine roots, supporting hypothesis two.

The nitrogen content of branchlets and fine roots was lower in the summer and autumn, when $C$. equisetifolia grows actively, than in the other seasons. Aerts et al. (1999) has proposed a mechanism by which summer warming reduces $\mathrm{N}$ content of leaves in Rubus. First, a portion of $\mathrm{N}$ is transferred to other plant parts, such as flowers. Incidentally, the flowering period peaks from April to June for C. equisetifolia. Second, a mass accumulation of branchlets and fine roots dilutes $\mathrm{N}$ content during spring and summer, when $C$. equisetifolia grows rapidly. In this study, the TP and TCT contents were inversely related to $\mathrm{N}$ content, especially in the fine roots. This negative relationship was also found between both TP and TCT with P content in branchlets and in fine roots. A negative correlation is commonly found between nutrient and secondary compound contents, such as phenolics and tannins (Mansfield et al. 1999; Shan et al. 2018). Some previous studies (Kosola et al. 2006; Kraus et al. 2004; Moore et al. 2000) have also indicated that nutrient availability affects root defense; root phenolics or condensed tannin concentrations may increase as $\mathrm{N}$ availability decreases. These results support the source-sink hypotheses, including the CNB hypothesis (Bryant et al. 1983) and the GDB hypothesis (Herms and Mattson 1992). Both predict that the allocation of $\mathrm{C}$ to secondary $\mathrm{C}$ compounds increases in nutrient-poor conditions, and they also support hypothesis two. However, the assumption that nutrient availability is elevated and carbon-based secondary metabolites are reduced during fast phases of growth was supported by four species, but not two others (Scogings et al. 2014). Finally, other studies have suggested that foliar $\mathrm{N}$ fails to induce an increase in condensed tannins and that condensed tannins are not affected by fertilization (Clemensen et al. 2017; Hattas et al. 2017). These contradictory results could result from differences in the type and concentration of fertilizer, as well as which plant parts were sampled (Clemensen et al. 2017). Some other studies showed that the differences in plant species and study systems also could be responsible for the inconsistent results (Keinänen et al. 1999; Wurzburger and Hendrick 2009). They considered that some plant species may only obtain nutrients through their own mycorrhizae, and that some plant species produce more 
secondary metabolites when $\mathrm{N}$ availability increases to reduce herbivory.

We found no significant correlation between absolute concentrations of $\mathrm{N}, \mathrm{TP}$ and TCT in fine roots or in branchlets. However, TP/N and TCT/N ratios in branchlets and in fine roots both increased initially, then decreased across all seasons, indicating a strong correlation between branchlets and fine roots. $\mathrm{TP} / \mathrm{N}$ and $\mathrm{TCT} / \mathrm{N}$ ratios in branchlets and in fine roots were highest in autumn and summer, respectively, which was similar to the TP and TCT contents. In general, the TCT/N ratio in fine roots was higher than in branchlets, which indicates that the resistance to herbivores was stronger in fine roots than in branchlets because a high $\mathrm{TP} / \mathrm{N}$ or $\mathrm{TCT} / \mathrm{N}$ ratio may help reduce herbivory.

The capacity of tannins to bind to proteins was related to the molecular size of the tannins (Makkar et al. 1987). Osborne and McNeill (2001) found that larger condensed tannin molecules precipitated more proteins than the smaller-sized hydrolyzable tannins. In accordance with the above finding, a stronger correlation was measured in the present study between TCT and PPC than between TP and PPC in branchlets and fine roots. Although TCT content in branchlets was lower than in fine roots in the spring and summer, the PPC content in branchlets was significantly higher than in fine roots. The relationship between TCT and PPC was stronger in branchlets than in fine roots. These results indicate that branchlets contain more largemolecule condensed tannins than do fine roots.

Tannins play an important role in many ecological processes, such as herbivore defense, litter decomposition, nutrient cycling, nitrogen sequestration and microbial activity (Henneron et al. 2017; Kraus et al. 2003). In green foliage and living roots, high tannin contents may help reduce herbivory (Chen et al. 2012). On the other hand, tannins may provide a nutrient conservation mechanism by slowing decomposition rates and lowering the $\mathrm{N}$ leaching potential of litter (Chomel et al. 2014; Masbough et al. 2005; Zhang et al. 2012). The slow decomposition rate of C. equisetifolia litter prevents nutrient loss from the infertile sandy soils (Ye et al. 2012; Zhang et al. 2013). Thus, high tannin production may be an important survival strategy for $C$. equisetifolia in its arid and infertile habitat.

\section{Conclusions}

Our results showed that tannin contents in branchlets and fine roots varied significantly across seasons. TP and TCT content in branchlets was positively correlated with air temperature and was highest in summer and autumn, when nitrogen content was lowest. Nevertheless, fine roots produced more TP and TCT in the summer, when the precipitation was relatively heavy. These results support the source-sink hypotheses and indicate that tannin content in branchlets is mainly affected by temperature and by precipitation in fine roots. Branchlets of $C$. equisetifolia contained much higher concentrations of TP and TCT than in fine roots. On the other hand, branchlets contained more large-molecule condensed tannins, which enhanced their ability to defend themselves effectively against herbivores. Thus, branchlets may be under more intense selection pressure than fine roots. We only examined tannin and nutrient content in branchlets and in fine roots and their relationship across seasons. Further work is required to investigate the influence of temperature and soil moisture on differences in the tannin structure between fine roots and branchlets.

Acknowledgements We thank Elizabeth Tokarz at Yale University for her assistance with English language and editing of the manuscript.

Open Access This article is distributed under the terms of the Creative Commons Attribution 4.0 International License (http://crea tivecommons.org/licenses/by/4.0/), which permits unrestricted use, distribution, and reproduction in any medium, provided you give appropriate credit to the original author(s) and the source, provide a link to the Creative Commons license, and indicate if changes were made.

\section{References}

Aerts RJ, Barry TN, McNabb WC (1999) Polyphenols and agriculture: beneficial effects of proanthocyanidins in forages. Agr Ecosyst Environ 75(1-2):1-12

Bettaieb I, Hamrouni-Sellami I, Bourgou S, Limam F, Marzouk B (2011) Drought effects on polyphenol composition and antioxidant activities in aerial parts of Salvia officinalis L. Acta Physiol Plant 33(4):1103-1111

Bryant JP, Chapin FS, Klein DR (1983) Carbon/nutrient balance of boreal plants in relation to vertebrate herbivory. Oikos 40(3):357-368

Bucchetti B, Matthews MA, Falginella L, Peterlunger E, Castellarin SD (2011) Effect of water deficit on Merlot grape tannins and anthocyanins across four seasons. Sci Hortic 128(3):297-305

Chen JZ, Zhang HY, Han ZP, Ye JY, Liu ZL (2012) The influence of aquatic macrophytes on Microcystis aeruginosa growth. Ecol Eng 42:130-133

Chomel M, Fernandez C, Bousquet-Melou A, Gers C, Monnier Y, Santonja M, Gauquelin T, Gros R, Lecareux C, Baldy V (2014) Secondary metabolites of Pinus halepensis alter decomposer organisms and litter decomposition during afforestation of abandoned agricultural zones. J Ecol 102(2):411-424

Clemensen AK, Provenza FD, Lee ST, Gardner DR, Rottinghaus GE, Villalba JJ (2017) Plant secondary metabolites in alfalfa, birdsfoot trefoil, reed canarygrass, and tall fescue unaffected by two different nitrogen sources. Crop Sci 57(2):964-970

Covelo F, Gallardo A (2001) Temporal variation in total leaf phenolics concentration of Quercus robur in forested and harvested stands in northwestern Spain. Can J Bot 79(11):1262-1269 
Duda SC, Mărghitaş LA, Dezmirean D, Duda M, Mărgăoan R, Bobiş $\mathrm{O}$ (2015) Changes in major bioactive compounds with antioxidant activity of Agastache foeniculum, Lavandula angustifolia, Melissa officinalis and Nepeta cataria: Effect of harvest time and plant species. Ind Crops Prod 77:499-507

Hagerman AE (1987) Radial diffusion method for determining tannin in plant extracts. J Chem Ecol 13(3):437-449

Hagerman AE (2011) The tannin handbook. https://www.users. muohio.edu/hagermae. Accessed 6 June 2019

Hattas D, Scogings PF, Julkunen-Tiitto R (2017) Does the growth differentiation balance hypothesis explain allocation to secondary metabolites in Combretum apiculatum, an African savanna woody species? J Chem Ecol 43(2):153-163

Henneron L, Chauvat M, Archaux F, Akpa-Vinceslas M, Bureau F, Dumas Y, Mignot L, Ningre F, Perret S, Richter C (2017) Plant interactions as biotic drivers of plasticity in leaf litter traits and decomposability of Quercus petraea. Ecol Monogr 87(2):321-340

Herms DA, Mattson WJ (1992) The dilemma of plants: to grow or defend. Q Rev Biol 67(3):283-335

Hernes PJ, Hedges JI (2000) Determination of condensed tannin monomers in environmental samples by capillary gas chromatography of acid depolymerization extracts. Anal Chem 72(20):5115-5124

Hernes PJ, Benner R, Cowie GL, Goni MA, Bergamaschi BA, Hedges JI (2001) Tannin diagenesis in mangrove leaves from a tropical estuary: A novel molecular approach. Geochim Cosmochim Ac 65(18):3109-3122

Institute of Soil Science, Chinese Academy of Sciences, (1978) Physico-chemical analysis of soils. Shanghai Science and Technology Press, Shanghai

Izquierdo AM, Torres MPN, Jimenez GS, Sosa FC (2011) Changes in biomass allocation and phenolic compounds accumulation due to the effect of light and nitrate supply in Cecropia peltata plants. Acta Physiol Plant 33(6):2135-2147

Keinänen M, Julkunen-Tiitto R, Mutikainen P, Walls M, Ovaska J, Vapaavuori E (1999) Trade-offs in phenolic metabolism of silver birch: effects of fertilization, defoliation, and genotype. Ecology 80(6):1970-1986

Kim SM, Kang SW, Jeon JS, Jung YJ, Kim WR, Kim CY, Um BH (2013) Determination of major phlorotannins in Eisenia bicyclis using hydrophilic interaction chromatography: seasonal variation and extraction characteristics. Food Chem 138(4):2399-2406

Kleiner KW, Raffa KF, Dickson RE (1999) Partitioning of ${ }^{14} \mathrm{C}$ labeled photosynthate to allelochemicals and primary metabolites in source and sink leaves of aspen: evidence for secondary metabolite turnover. Oecologia 119(3):408-418

Koricheva J (1999) Interpreting phenotypic variation in plant allelochemistry: problems with the use of contents. Oecologia 119(4):467-473

Kosola KR, Parry D, Workmaster BAA (2006) Responses of condensed tannins in poplar roots to fertilization and gypsy moth defoliation. Tree Physiol 26(12):1607-1611

Kraus TEC, Dahlgren RA, Zasoski RJ (2003) Tannins in nutrient dynamics of forest ecosystems: a review. Plant Soil 256(1):41-66

Kraus TEC, Zasoski RJ, Dahlgren RA (2004) Fertility and pH effects on polyphenol and condensed tannin concentrations in foliage and roots. Plant Soil 262(1-2):95-109

Li CM, Wang Y, Yu WX (2011) Dynamic changes of phenolic compound contents in leaf and bark of poplar during autumn temperature drop. J For Res 22(3):481-485

Lim TY, Lim YY, Yule CM (2017) Distribution and characterization of phenolic compounds in Macaranga pruinosa and associated soils in a tropical peat swamp forest. J Trop For Sci 29(4):509-518
Lin YM, Liu JW, Xiang P, Lin P, Ye GF, Sternberg LdSL (2006) Tannin dynamics of propagules and leaves of Kandelia candel and Bruguiera gymnorrhiza in the Jiulong River Estuary, Fujian, China. Biogeochemistry 78(3):343-359

Makkar HPS, Dawra RK, Singh B (1987) Protein precipitation assay for quantitation of tannins: determination of protein in tanninprotein complex. Anal Biochem 166(2):435-439

Mannino AM Vaglica V Cammarata M Oddo E (2016) Effects of temperature on total phenolic compounds in Cystoseira amentacea (C. Agardh) Bory (Fucales, Phaeophyceae) from southern Mediterranean Sea Plant Biosyst 1502152160

Mansfield JL, Curtis PS, Zak DR, Pregitzer KS (1999) Genotypic variation for condensed tannin production in trembling aspen (Populs tremuloides, Salicaceae) under elevated $\mathrm{CO}_{2}$ and in high- and low-fertility soil. Am J Bot 86(8):1154-1159

Masbough A, Frankowski K, Hall KJ, Duff SJB (2005) The effectiveness of constructed wetland for treatment of woodwaste leachate. Ecol Eng 25(5):552-566

Massad TJ, Trumbore SE, Ganbat G, Reichelt M, Unsicker S, Boeckler A, Gleixner G, Gershenzon J, Ruehlow S (2014) An optimal defense strategy for phenolic glycoside production in Populus trichocarpa-isotope labeling demonstrates secondary metabolite production in growing leaves. New Phytol 203(2):607-619

Moore JA, Mika PG, Shaw TM (2000) Root chemistry of mature Douglas-fir differs by habitat type in the interior northwestern United States. For Sci 46(4):531-536

Naumann HD, Coope CE, Muir JP (2017) Seasonality affects leaf nutrient and condensed tannin concentration in southern African savannah browse. Afr J Ecol 55(2):168-175

Osborne NJT, McNeill DM (2001) Characterisation of Leucaena condensed tannins by size and protein precipitation capacity. J Sci Food Agric 81(11):1113-1119

Pacifico S, Galasso S, Piccolella S, Kretschmer N, Pan SP, Marciano S, Bauer R, Monaco P (2015) Seasonal variation in phenolic composition and antioxidant and anti-inflammatory activities of Calamintha nepeta (L.) Savi. Food Res Int 69:121-132

Penuelas J, Estiarte M (1998) Can elevated $\mathrm{CO}_{2}$ affect secondary metabolism and ecosystem function? Tree 13:20-24

Pinyopusarerk K, Williams ER (2000) Range-wide provenance variation in growth and morphological characteristics of $\mathrm{Ca}$ suarina equisetifolia grown in Northern Australia. For Ecol Manag 134(1-3):219-232

Randriamanana TR, Lavola A, Julkunen-Tiitto R (2015) Interactive effects of supplemental UV-B radiation and temperature in European aspen seedlings: Implications for growth, leaf traits, phenolic defense and associated organisms. Plant Physiol Biochem 93:84-93

Riipi M, Ossipov V, Lempa K, Haukioja E, Koricheva J, Ossipova S, Pihlaja K (2002) Seasonal changes in birch leaf chemistry: are there trade-offs between leaf growth, and accumulation of phenolics? Oecologia 130(3):380-390

Scogings PF, Hjalten J, Skarpe C, Hattas D, Zobolo A, Dziba L, Rooke T (2014) Nutrient and secondary metabolite concentrations in a savanna are independently affected by large herbivores and shoot growth rate. Plant Ecol 215(1):73-82

Shan LP, Song CC, Zhang XH, Ren JS (2018) Effects of long-term nitrogen and phosphorus addition on plant defense compounds in a freshwater wetland. Ecol Indic 94(1):1-6

Sobuj N, Virjamo V, Zhang YD, Nybakken L, Julkunen-Tiitto R (2018) Impacts of elevated temperature and $\mathrm{CO}_{2}$ concentration on growth and phenolics in the sexually dimorphic Populus tremula (L.). Environ Exp Bot 146:34-44

Terrill T, Rowan A, Douglas G, Barry T (1992) Determination of extractable and bound condensed tannin concentrations in forage 
plants, protein concentrate meals and cereal grains. J Sci Food Agric 58(3):321-329

Top SM, Preston CM, Dukes JS, Tharayil N (2017) Climate influences the content and chemical composition of foliar tannins in green and senesced tissues of Quercus rubra. Front Plant Sci 8:423

Usami T, Lee J, Oikawa T (2001) Interactive effects of increased temperature and $\mathrm{CO}_{2}$ on the growth of Quercus myrsinaefolia saplings. Plant Cell Environ 24:1007-1019

Wam HK, Stolter C, Nybakken L (2017) Compositional changes in foliage phenolics with plant age, a natural experiment in boreal forests. J Chem Ecol 43(9):920-928

Wang WJ, Zu YG, Li XY (2007) Seasonal change and organs difference of tannin content in Larix gmelinii. Chem Ind For Prod 27(2):81-84

Wang WJ, Li WX, Xu HN, Zu YG, Wang Y (2008) Characters of life cycle forms of Chelidonium majus populations indifferent habitats and their correlation to the contents of tannin, flavones and alkaloids in diffferent organs. Acta Ecol Sin 28(11):5228-5237

Wright SJ, Kitajima K, Kraft NJB, Reich PB, Wright IJ, Bunker DE, Condit R, Dalling JW, Davies SJ, Diaz S, Engelbrecht BMJ, Harms KE, Hubbell SP, Marks CO, Ruiz-Jaen MC, Salvador CM, Zanne AE (2010) Functional traits and the growth-mortality trade-off in tropical trees. Ecology 91(12):3664-3674

Wurzburger N, Hendrick RL (2009) Plant litter chemistry and mycorrhizal roots promote a nitrogen feedback in a temperate forest. J Ecol 97(3):528-536

Yang LG, Yin PP, Li K, Fan H, Xue Q, Li X, Sun LW, Liu YJ (2018) Seasonal dynamics of constitutive levels of phenolic conponents lead to alterations of antioxidant capacities in Acer truncatum leaves. Arab J Chem 11(1):14-25

Ye GF, Zhang SJ, Zhang LH, Lin YM, Wei SD, Liao MM, Lin GH (2012) Age-related changes in nutrient resorption patterns and tannin concentration of Casuarina equisetifolia plantations. J Trop For Sci 24(4):546-556

Zhang LH, Lin YM, Ye GF, Liu XW, Lin GH (2008) Changes in the $\mathrm{N}$ and $\mathrm{P}$ concentrations, $\mathrm{N}$ : $\mathrm{P}$ ratios, and tannin content in Casuarina equisetifolia branchlets during development and senescence. J For Res 13(5):302-311

Zhang LH, Ye GF, Lin YM, Zhou HC, Zeng Q (2009) Seasonal changes in tannin and nitrogen contents of Casuarina equisetifolia branchlets. J Zhejiang Univ (Sc B) 10(2):103-111

Zhang LH, Shao HB, Ye GF, Lin YM (2012) Effects of fertilization and drought stress on tannin biosynthesis of Casuarina equisetifolia seedlings branchlets. Acta Physiol Plant 34(5):1639-1649

Zhang LH, Zhang SJ, Ye GF, Shao HB, Lin GH, Brestic M (2013) Changes of tannin and nutrients during decomposition of branchlets of Casuarina equisetifolia plantation in subtropical coastal areas of China. Plant Soil Environ 59(2):74-79

Zhou HC, Wei SD, Zeng Q, Zhang LH, Tam NF, Lin YM (2010) Nutrient and caloric dynamics in Avicennia marina leaves at different developmental and decay stages in Zhangjiang River Estuary, China. Estuar Coast Shelf S 87(1):21-26

Publisher's Note Springer Nature remains neutral with regard to jurisdictional claims in published maps and institutional affiliations. 